Egyptian Journal of Aquatic Biology \& Fisheries

Zoology Department, Faculty of Science,

Ain Shams University, Cairo, Egypt.

ISSN $1110-6131$

Vol. 24(5): 375 - 392 (2020)

www.ejabf.journals.ekb.eg

\title{
Spatial and temporal size structure abundance of the blue swimming crab (Portunus pelagicus) in Tiworo Strait, Southeast Sulawesi, Indonesia
}

\author{
Oce Astuti ${ }^{1}$, Naslina Alimina ${ }^{2}$, La Sara ${ }^{3} *$, Emi Emiyarti ${ }^{4}$, and Ani Rahmadani ${ }^{4}$ \\ ${ }^{1}$ Department of Aquaculture of Faculty of Fisheries and Marine Science, Halu Oleo University. \\ Bumi Tridharma, Kendari 93232, Southeast Sulawesi, Indonesia \\ ${ }^{2}$ Study Program of Fish Capture of Faculty of Fisheries and Marine Science, Halu Oleo \\ University. Bumi Tridharma, Kendari 93232, Southeast Sulawesi, Indonesia \\ ${ }^{3}$ Department of Aquatic Resources Management of Faculty of Fisheries and Marine Science, \\ Halu Oleo University. Bumi Tridharma, Kendari 93232, Southeast Sulawesi, Indonesia \\ ${ }^{4}$ Department of Marine Science of Faculty of Fisheries and Marine Science, Halu Oleo \\ University. Bumi Tridharma, Kendari 93232, Southeast Sulawesi, Indonesia
}

*Corresponding Author: lasara_unhalu@yahoo.com

\section{ARTICLE INFO}

Article History:

Received: July 21, 2020

Accepted: Aug. 10, 2020

Online: Aug. 14, 2020

Keywords:

Abundance,

Sex ratio,

Size structure,

Spatial and temporal,

Portunus pelagicus

\section{INTRODUCTION}

This study aimed to analyze spatial and temporal size abundance and sex ratio patterns of blue swimming crab (BSC). It was conducted from June to December 2018. Samples were taken monthly using collapsible pots and gillnets from different habitat characteristics of intertidal (station A), river mouth (station B), seagrass (station $\mathrm{C}$ and $\mathrm{D}$ ), and depth of $>30 \mathrm{~m}$ (station E). Each sample was sexed, measured its $\mathrm{CW}(\mathrm{cm})$, and weighed its body weight $(\mathrm{g})$. Those were classified according to sex and CW into: $<6.0 \mathrm{~cm}$ (juvenile), $\geq 6.0-9.0 \mathrm{~cm}$ (mature), and $\geq 9.0 \mathrm{~cm}$ (adult) and counted to perform abundance and sex ratio of each station and month. Results showed that juveniles were more abundant in station A, while mature abundance has no distribution pattern. Adults tended to be abundant in station E. Those may affect sex ratio in all stations and months. Male juvenile sex ratio preponderated over female in station A, while in other stations have no pattern. On the contrary, mature females preponderated over males in station A, but have no pattern in other stations, while adults showed females preponderated over males in station E. It implies that females of the blue swimming crab $(\mathrm{BSC}=$ Portunus pelagicus) prefer deep water having high salinity to release eggs.

The blue swimming crab (BSC = Portunus pelagicus) has been widely studied around the world due to its widely distributed which occurs in the entire of Indian and Indo-West Pacific Oceans including Japan, Philippines, Malaysia, Brunei Darrusalam, eastern Australia, Fiji Island, Red Sea and East Africa (Williams, 1982, Edgar, 1990, Potter and de Lestang, 2000, Johnston et al., 2011), Indonesia (La Sara et al., 2016a) and extends eastwards in the Pacific to Hawaiian waters (Apel and Spiridonov, 1998). 
This species typically inhibits sandy oceanic habitats to a depth of $30 \mathrm{~m}$ (Carpenter $\boldsymbol{e t}$ al., 1997, La Sara et al. 2016a).

It is well known that Indonesian water is one of BSC habitats in the Indo Pacific regions as shown its wide distribution extending in the entire of its coastal waters from Western Sumatera, northern Java (Java Sea), around South and Southeast Sulawesi up to eastern part of Papua. In Indonesia this species occupies coastal and estuarine waters in the intertidal zones, river mouth and extends forward to water depth of $50 \mathrm{~m}$ (La Sara $\boldsymbol{e t}$ al. 2016a, 2017). It lives in a variety of inshore and continental shelf areas, including sandy mixed with muddy adjacent mangrove area or algal and seagrass habitats (Kailola et al., 1993, La Sara et al. 2016a). BSCs move to deeper water as they mature and in response to water temperature and salinity (Kailola $\boldsymbol{e t}$ al., 1993). This species is consumed by many people due to its high protein and is to be one of the most important species for small-scale commercial fisheries around Indonesian waters, aside other crustacean of shrimps, mud crabs, and lobsters (La Sara et al., 2016a).

This species has been exploited since last 3 decades using unselective collapsible crab pots and bottom gillnets. There is trawling operation for shrimps taking a considerable number of BSCs as by-catch (La Sara et al., 2016b, 2016c). In this waters, fishermen catch all BSC CW sizes due to all crab meat processing mini plants accepting those sizes. Massive cutting mangrove trees around coastal area for jetty, road and housing are somethings hard to be rejected in the remote areas. Those are considerably the main problems faced in BSC management in order to sustain its population.

Some studies conducted around Indonesian coastal waters show high exploitation on this species as indicated by (1) its carapace width (CW) size is dominated by small size of $<7 \mathrm{~cm}$, (2) CPUE is few and the sizes have been declining for several years (Zairion et al., 2015), and (3) its fishing ground is limited and moving afield from shore line (La Sara et al 2016a, 2016b). The study on experimental fishing conducted in Australia mainly to develop and test commercially viable gear for targeting crabs but met with little success (Xiao and Kumar, 2004). La Sara et al. (2016c) have recommended to the fishermen to use rectangular collapsible pots using escape vent size of $4.5 \mathrm{~cm} \times 5.0$ $\mathrm{cm}$ which is put in both sides of crab pot.

Although many studies on this species have been conducted such as selective fishing gear design (La Sara et al., 2016b), reproductive biology (Zairion et al., 2015, La Sara et al., 2016a, Basri et al., 2017, Hisam et al., 2018), population parameters (La Sara et al., 2017, Muchtar et al., 2017), harvest control rule (La Sara et al., 2016b), mapping fishing ground, however, there is paucity studies explain spatial and temporal distribution of BSC size abundance in Indonesian waters. The objective of present study was to analyze the spatial and temporal of BSC sizes abundance distribution and sex ratio.

\section{MATERIALS AND METHODS}

\section{Design of study location}

Tiworo strait waters is a well known as BSC fishing ground in Southeast Sulawesi and in Indonesia in general. This fishing ground is surrounded by four main lands of South Konawe, Bombana, Muna, and West Muna. The location of study was purposively chosen at the BSC fishing ground in South Konawe (Fig. 1). All life cycles of BSC happen in this waters starting from copulation, mating, release eggs, hatching to be 
larvae, growing to be megalopa, juvenile, mature and adult. Sampling locations of BSCs were chosen according to habitat characteristics of BSC fishing ground, namely coastal waters grown mangroves (intertidal zone) (station A), river mouth (station B), coastal area with fine sand substrate grown few seagrasses (station C), coastal area grown heavy seagrass (station $\mathrm{D}$ ), and deep water of $>30 \mathrm{~m}$ (station E). The study was conducted from June to December 2018.

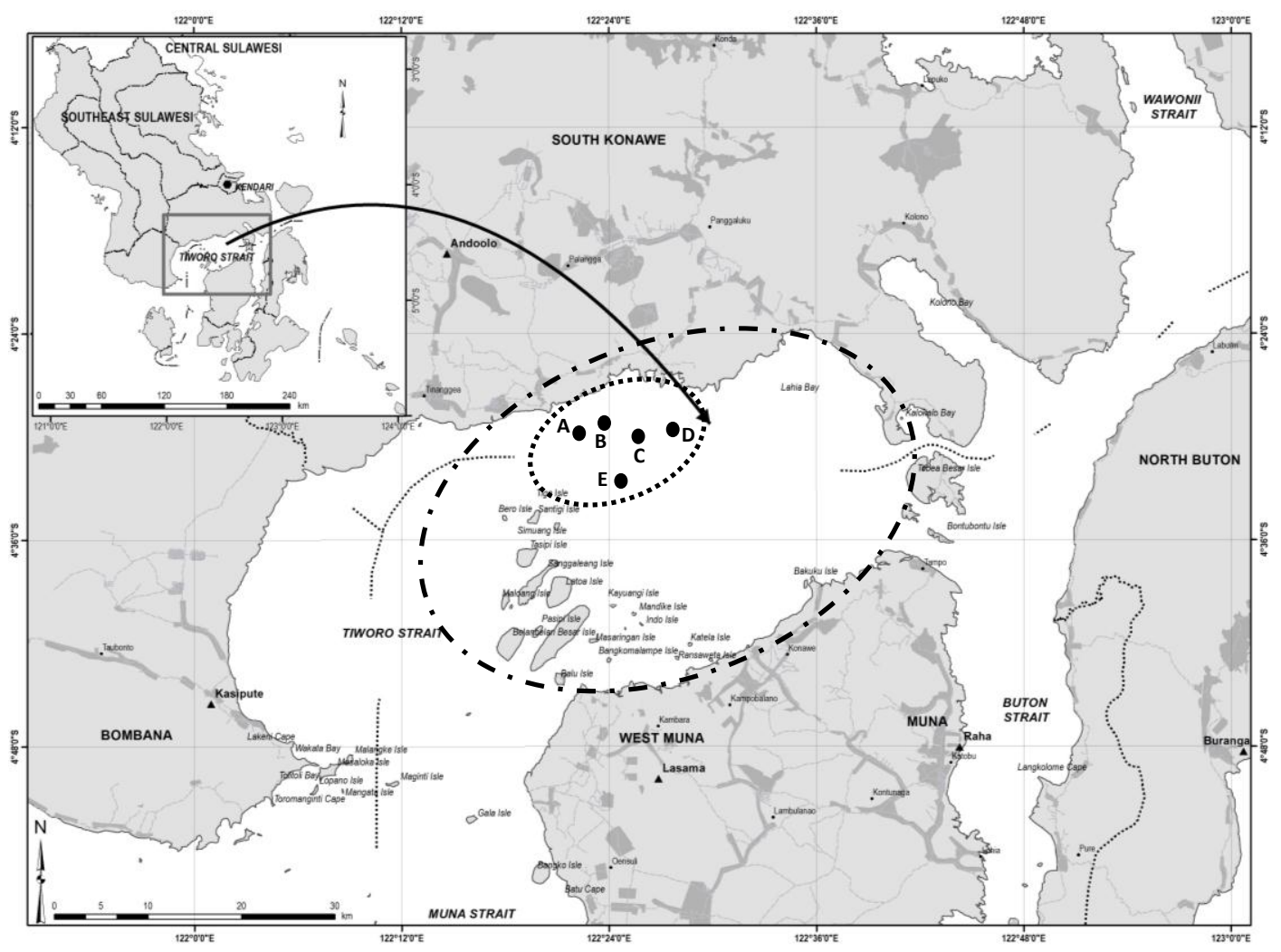

Fig. 1. Map of Tiworo Strait waters of Southeast Sulawesi (dash line is study locations and black circle is station of sampling of BSC. There are 5 stations (A, B, C, D and E) of sampling).

\section{Sampling Methods}

BSCs sampling at each station was taken monthly. Fishing gears used at station A D were collapsible rectangular collapsible crab pot (length $=54 \mathrm{~cm}$, width $=36 \mathrm{~cm}$, and height $=19 \mathrm{~cm}$ ) covered with nylon net of $\pm 0.5 \mathrm{~cm}$ mesh size (Fig. 2), while at station E was bottom gillnet. As many 150 units of crab pots were deployed at each station. Each crab pot was tied at main nylon polypropylene rope $(\mathscr{\varnothing}=0.5 \mathrm{~mm})$ using small nylon polypropylene $(\dot{\varnothing}=0.25 \mathrm{~mm})$. The distance between crab pots at main nylon polypropylene was $\pm 10 \mathrm{~m}$. Each crab pot was put fresh fish bait with size relatively the same at each crab pot. All crab pots tied in the main nylon polypropylene were deployed during flood tide then hauled at ebb tide. The BSC sampling at station E used a bottom gillnet of $1 \mathrm{~km}$ length, $1 \mathrm{~m}$ height, and 4 inch mesh size (Fig. 3). Each BSC sample caught at each station was recorded, sexed according to abdomen morphometric characteristics, measured its $\mathrm{CW}$ (to the base of the spines) using a caliper (to an accuracy of $0.1 \mathrm{~mm}$ ), weighed its body weight using electronic balance (to an accuracy of $1 \mathrm{~g}$ ), and then each sex counted its number (La Sara et al., 2016a, 2017). 


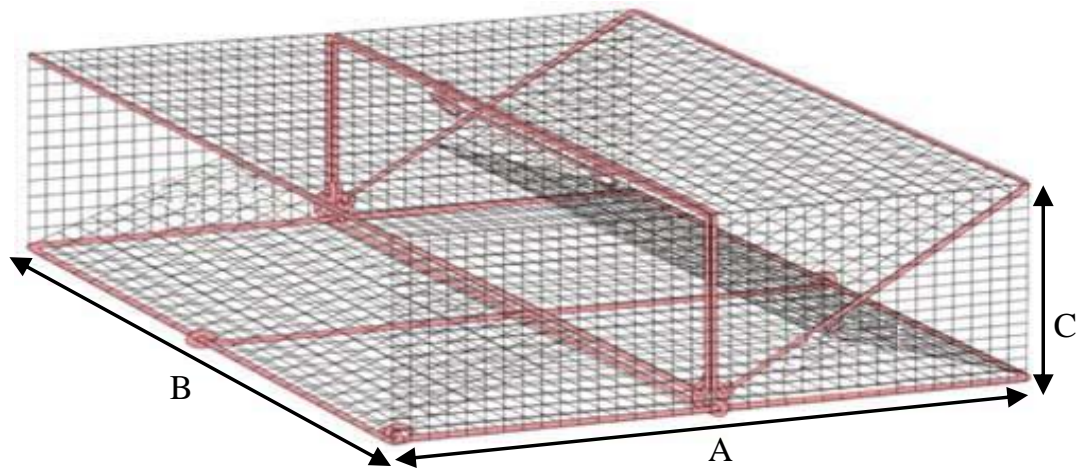

Fig. 2. Rectangular collapsible crab pot used for BSC sampling at stations $A-D$ in Tiworo Strait of Southeast Sulawesi (length, $A=54 \mathrm{~cm}$; width, $B=36 \mathrm{~cm}$ and height, $\mathrm{C}$ $=19 \mathrm{~cm})($ La Sara et al., 2016a).

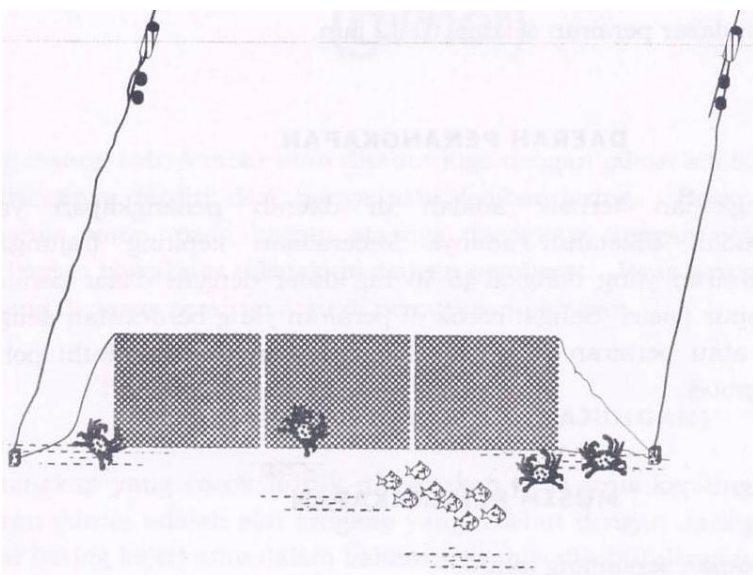

Fig. 3. Bottom gillnet used for BSC sampling at station E in Tiworo Strait of Southeast Sulawesi (length $= \pm 1 \mathrm{~km}$ and; height $=80-100 \mathrm{~cm}$, mesh size $=4.0$ inch) $($ La Sara $\boldsymbol{e t}$ al., 2019).

\section{Data Analysis}

\section{Abundance of CW size structure of BSC}

All BSC samples taken from each station (spatial) and month (temporal) were grouped (tabulated), then classified according to sex and $\mathrm{CW}$ of $<6.0 \mathrm{~cm}$ (juvenile), $\geq 6,0$ $-9.0 \mathrm{~cm}$ (mature), and $\geq 9,0 \mathrm{~cm}$ (adult). The abundance (number) of each size group and sex were counted according to station and month.

\section{Sex Ratio}

Males and females BSCs taken from each station and month were counted, and then sex was analyzed as follows:

$$
S R=\frac{\sum \text { Male }}{\sum \text { Female }}
$$

Significance of the sex ratio was tested using Chi-square test $(\alpha=0.05)$ (Sudjana, 1989, La Sara et al., 2016b), as follows: 


$$
\chi^{2}=\sum_{k=0}^{n} \frac{(\mathrm{O}-\mathrm{E})^{2}}{\mathrm{E}}
$$

Note: $\chi^{2}=$ Chi-square, $\mathrm{O}=$ frequency number of observed male and female BSCs, $\mathrm{E}=$ frequency number of expected male and female BSCs.

\section{RESULTS}

\section{Spatial and Temporal Abundance of CW size structure}

\subsection{Abundance of Juveniles $(\mathrm{CW}<6.0 \mathrm{~cm})$}

Abundance of juvenile BSCs $(\mathrm{CW}<6.0 \mathrm{~cm})$ of both sexes was always high in station A compared to other 4 stations in almost months (June - December) (Fig. 4). The juvenile BSCs at station B and D had high abundance in the same months (November), while at station $\mathrm{C}$ was found in July. Abundance of juvenile BSCs at station E was only found in November which was very few (Fig. 5).

\subsection{Abundance of Matures $(C W \geq 6.0-9.0 \mathrm{~cm})$}

The present results showed that mature BSCs $(\mathrm{CW} \geq 6.0-9.0 \mathrm{~cm})$ were more abundant at station A. This size was abundant only in November at station B, while at stations C and D was abundant in August - October and August - November, respectively and only in November at station E (Fig. 6 and 7). However, both males and females of this size were relatively distinguished its abundance. The female BSCs generally were more abundant than that of males, particularly at station A (unless November), station B (November), station C (August), and station D (November).

\subsection{Abundance of Adults $(\mathrm{CW}>9.0 \mathrm{~cm})$}

The adult BSCs $(\mathrm{CW}>9.0 \mathrm{~cm})$ of both males and females were was still found at station A. Their number was relatively similar at stations D and E, while at stations B and $\mathrm{C}$ was very few (Fig. 8 and 9). The adult BSCs at intertidal zone (station A) was few compared to juveniles and matures due to those adult BSCs move to deep sea water particularly females. When those adult BSCs move to deep sea water (station E), they cross first seagrass habitats (stations $\mathrm{C}$ and D) and intertidal zone (station A).

\section{Spatial and Temporal Sex Ratio}

The results of sex ratio of juvenile BSCs showed that, males were generally preponderated over females, particularly at stations A and D. Sex ratio at stations B and C exhibited also males preponderated over females, but there was no juveniles were found in some months; while sex ratio at station $\mathrm{E}$ was only found in November with high ratio for males than females. However, overall sex ratio of M : F was 1.44 : 1 (Table 1). For mature BSCs, it was different, whereas females were mostly preponderated over males $(\mathrm{M}<\mathrm{F})$ at stations $\mathrm{A}$ and $\mathrm{B}$, but showed no regular pattern at stations $\mathrm{C}$ and $\mathrm{D}$. The sex ratio at station $\mathrm{E}$ was only found in October and November, where males preponderated over females. The overall sex ratio of $\mathrm{M}: \mathrm{F}$ was $1: 1.27$ (Table 2). The sex ratio showed no regular pattern and was also found in adult BSCs, particularly at stations A, B, C, and $\mathrm{E}$, but at station $\mathrm{D}$ tended to males preponderated over females. It showed that the overall sex ratio of $\mathrm{M}: \mathrm{F}$ adult BSCs was $1: 1.28$ (Table 3). 


\section{Frequency}

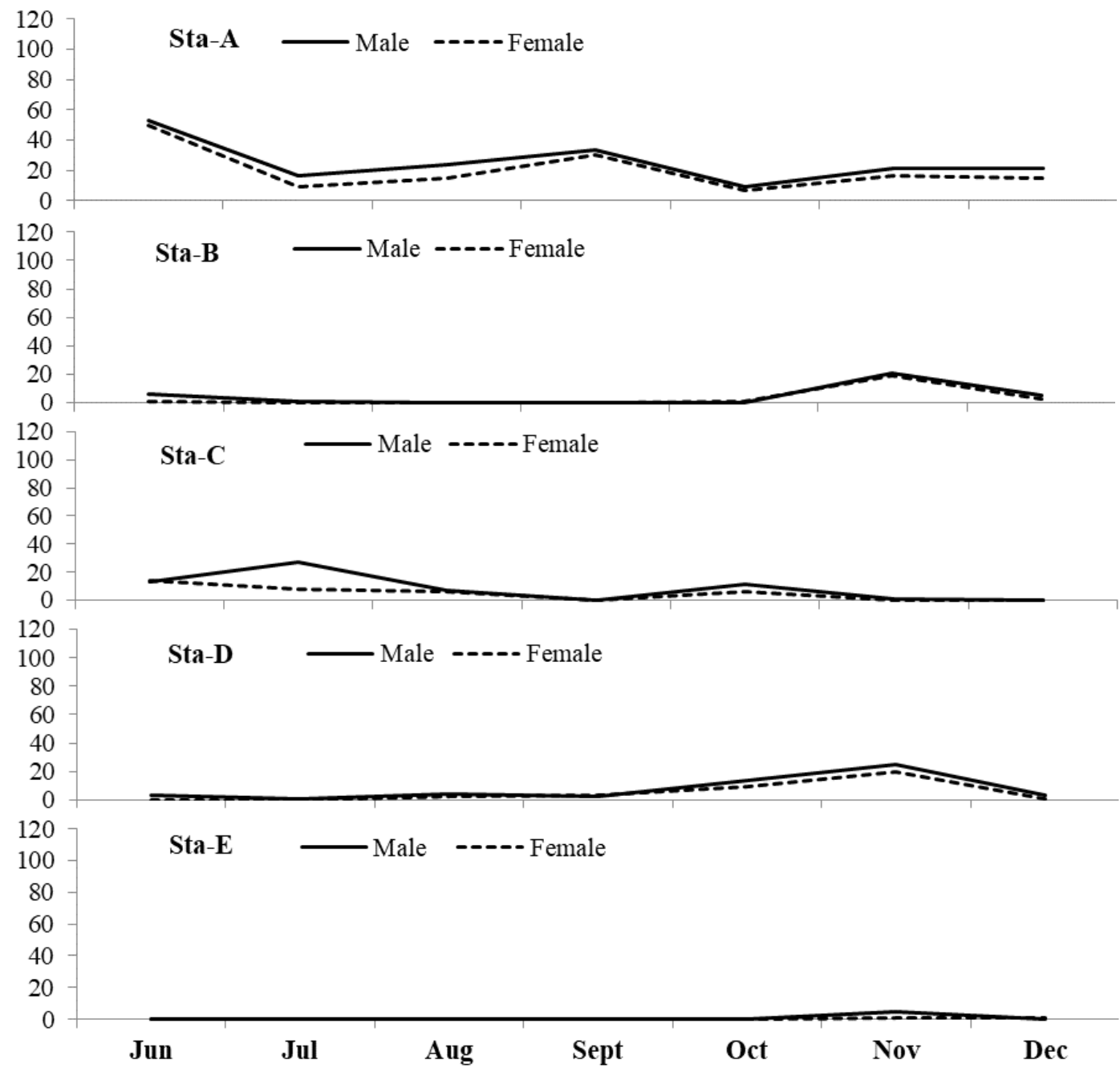

Fig. 4. Abundance of male and female BSCs of $<6.0 \mathrm{~cm} \mathrm{CW}$ according to stations (spatial) at each month (temporal) in Tiworo Strait waters of Southeast Sulawesi, Indonesia.

Table 1. Sex ratio (males : females) of the BSCs of $<6.0 \mathrm{CW}$ according to months (temporal) at each station (spatial) of Tiworo Strait of Southeast Sulawesi, Indonesia.

\begin{tabular}{ccccccccc}
\hline Station & Jun & Jul & Aug & Sept & Oct & Nov & Dec & $\begin{array}{c}\text { Overall } \\
\text { sex ratio }\end{array}$ \\
\hline Sta $-\mathbf{A}$ & $1.06: 1.00$ & $1.78: 1.00$ & $1.60: 1.00$ & $1.10: 1.00$ & $1.29: 1.00$ & $1.31: 1.00$ & $1.40: 1.00$ & $1.25: 1$ \\
$\mathbf{S t a}-\mathbf{B}$ & $6.00: 1.00$ & $1.00: 0$ & - & - & $0: 1.00$ & $1.11: 1.00$ & $1.67: 1.00$ & $1.38: 1$ \\
$\mathbf{S t a}-\mathbf{C}$ & $1.00: 1.08$ & $3.50: 1.00$ & $1.17: 1.00$ & - & $1.83: 1.00$ & $1.00: 0$ & - & $1.74: 1$ \\
$\mathbf{S t a}-\mathbf{D}$ & $3.00: 0$ & $1.00: 0$ & $2.00: 1.00$ & $1.00: 1.50$ & $1.56: 1.00$ & $1.25: 1.00$ & $3.00: 1.00$ & $1.49: 1$ \\
$\mathbf{S t a}-\mathbf{E}$ & - & - & - & - & - & $5.00: 1.00$ & $0: 1.00$ & $2.50: 1$ \\
\hline $\begin{array}{c}\text { Overall } \\
\text { Sex ratio }\end{array}$ & $1.15: 1$ & $2.65: 1$ & $1.52: 1$ & $1.06: 1$ & $1.48: 1$ & $1.30: 1$ & $1.44: 1$ & $1.44: 1$ \\
\hline
\end{tabular}




\section{Frequency}

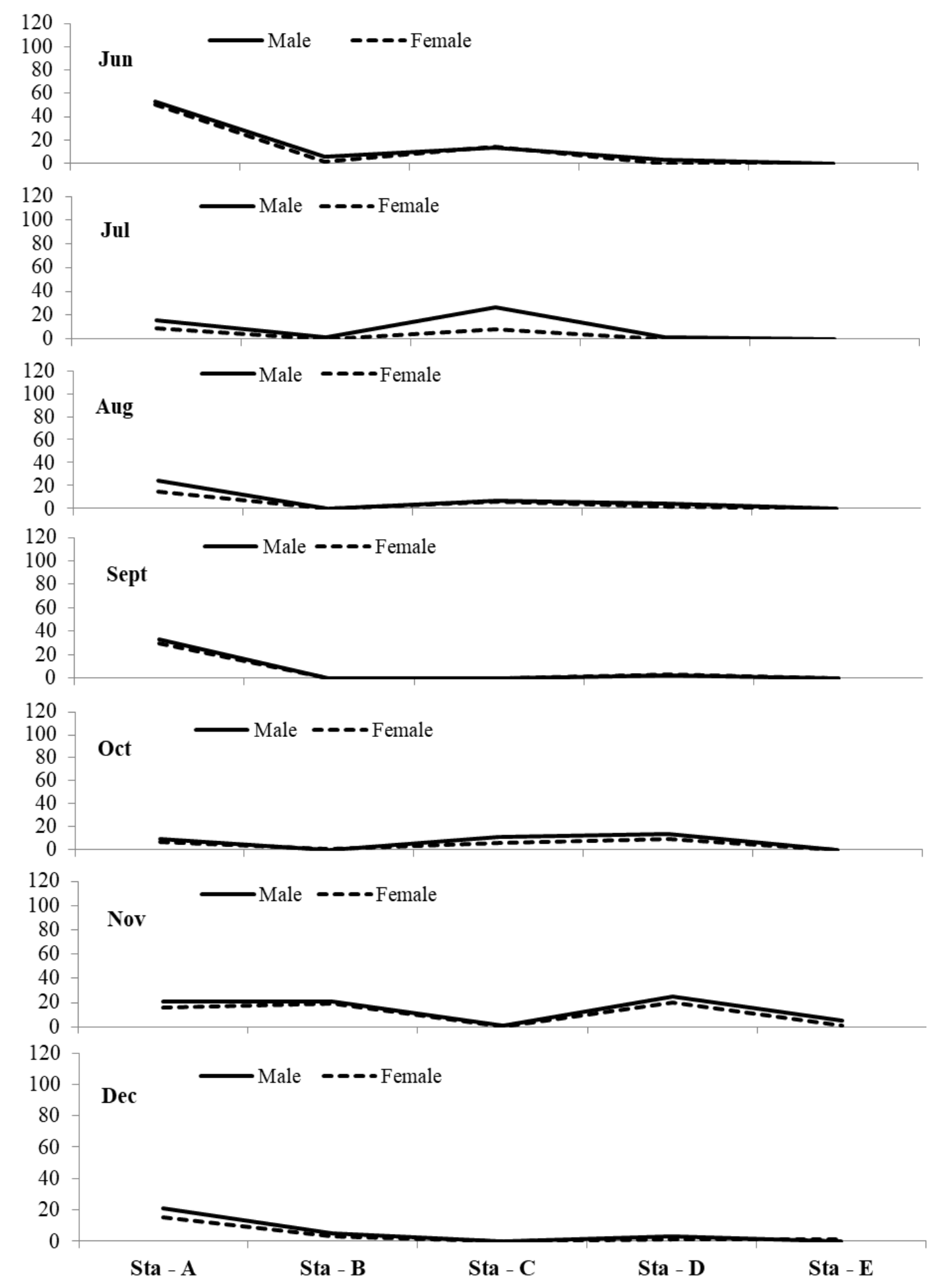

Fig. 5. Abundance of male and female BSCs of $<6.0 \mathrm{~cm} \mathrm{CW}$ according to months (temporal) at each station (spatial) in Tiworo Strait waters of Southeast Sulawesi, Indonesia. 


\section{Frequency}

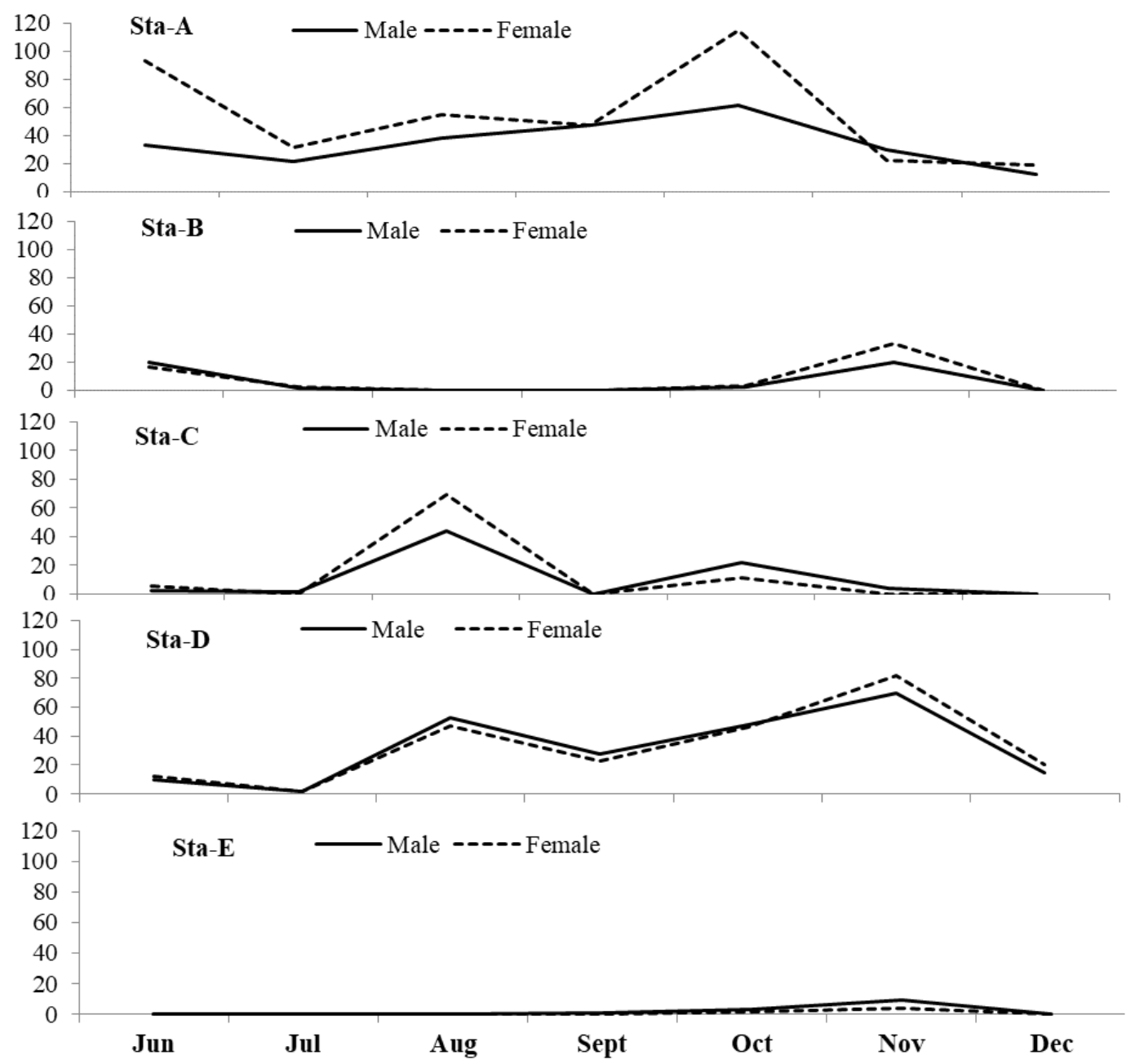

Fig. 6. Abundance of male and female BSCs of $\geq 6.0-9.0 \mathrm{~cm} \mathrm{CW}$ according to stations (spatial) at each month (temporal) in Tiworo Strait waters of Southeast Sulawesi, Indonesia.

Table 2. Sex ratio (males : females) of the BSC of $\geq 6.0-9.0 \mathrm{CW}$ according to months (temporal) at each station (spatial) of Tiworo Strait of Southeast Sulawesi, Indonesia.

\begin{tabular}{ccccccccc}
\hline Station & Jun & Jul & Aug & Sept & Oct & Nov & Dec & $\begin{array}{c}\text { Overall } \\
\text { sex ratio }\end{array}$ \\
\hline Sta $-\mathbf{A}$ & $1.00: 2.82$ & $1.00: 1.48$ & $1.00: 1.45$ & $1.00: 1.00$ & $1.00: 1.89$ & $1.36: 1.00$ & $1.00: 1.58$ & $1: 1.58$ \\
Sta $-\mathbf{B}$ & $1.25: 1.00$ & $1.00: 1.00$ & $0: 0$ & - & $1.00: 1.50$ & $1.00: 1.65$ & - & $1: 1.26$ \\
$\mathbf{S t a}-\mathbf{C}$ & $1.00: 2.50$ & $1.00: 0$ & $1.00: 1.57$ & - & $2.00: 1.00$ & $4.00: 0$ & - & $1: 1.16$ \\
$\mathbf{S t a}-\mathbf{D}$ & $1.00: 1.20$ & $1.00: 1.00$ & $1.13: 1.00$ & $1.22: 1.00$ & $1.04: 1.00$ & $1.00: 1.17$ & $1.00: 1.33$ & $1: 1.03$ \\
$\mathbf{S t a}-\mathbf{E}$ & - & - & - & $1.00: 0$ & $1.50: 1.00$ & $2.25: 1.00$ & - & $2.17: 1$ \\
\hline $\begin{array}{c}\text { Overall } \\
\text { Sex ratio }\end{array}$ & $1: 1.94$ & $1: 1.40$ & $1: 1.27$ & $1.09: 1$ & $1: 1.30$ & $1: 1.06$ & $1: 1.44$ & $1: 1.27$ \\
\hline
\end{tabular}




\section{Frequency (ind)}
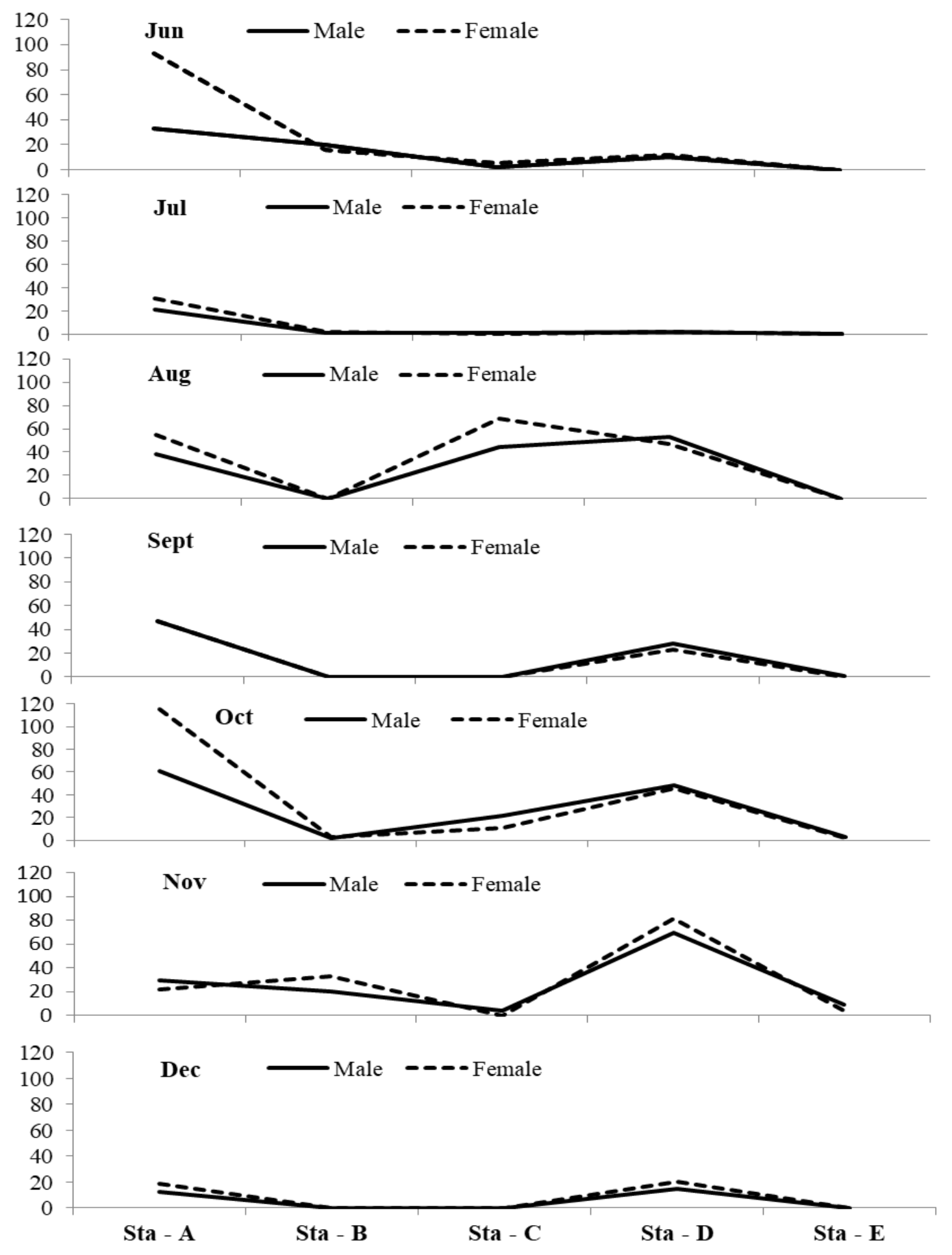

Fig. 7. Abundance of male and female BSCs of $\geq 6.0-9.0 \mathrm{~cm} \mathrm{CW}$ according to months (temporal) at each station (spatial) in Tiworo Strait waters of Southeast Sulawesi, Indonesia. 


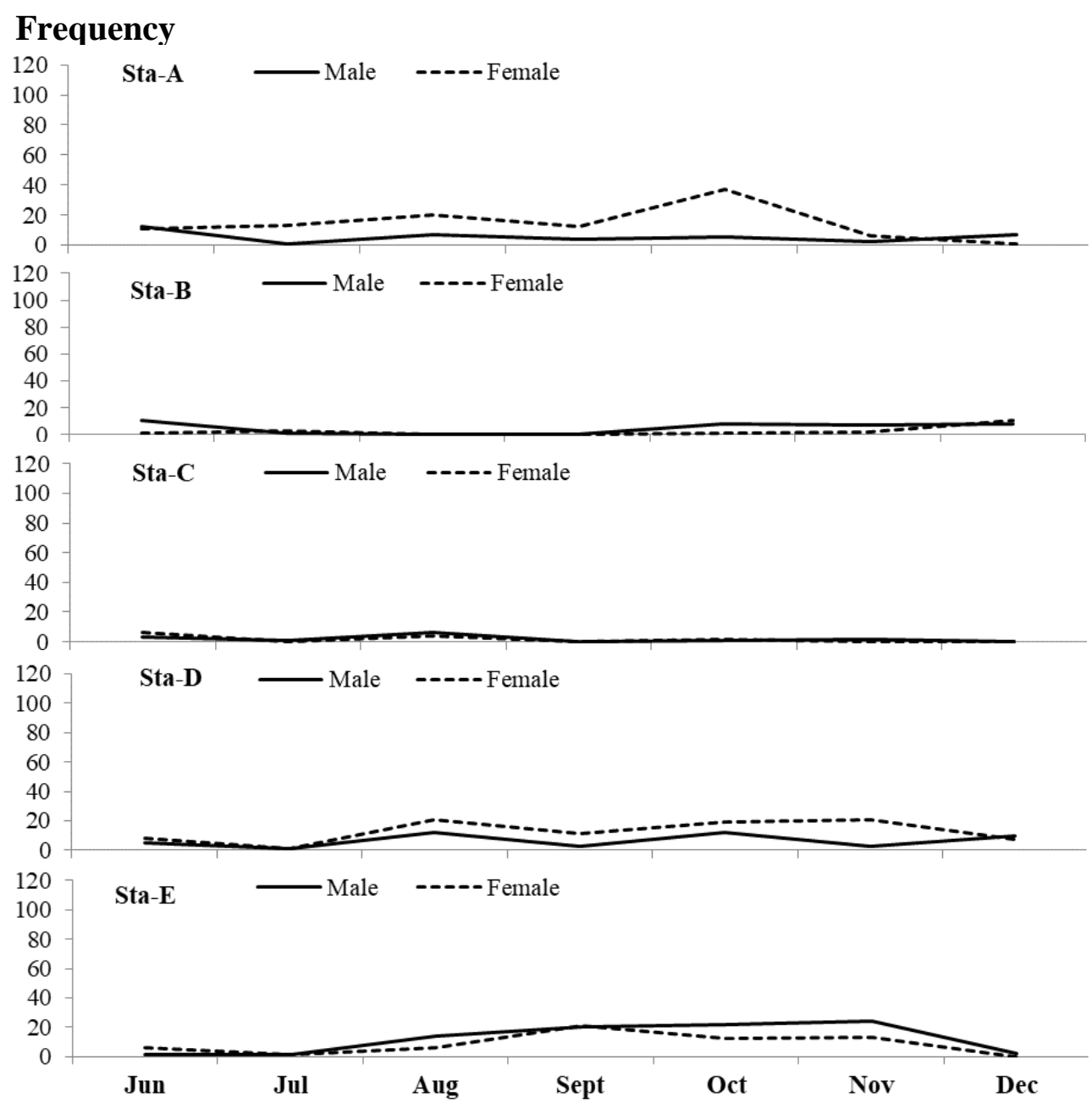

Fig. 8. Abundance of male and female BSCs of $\geq 9.0 \mathrm{~cm} \mathrm{CW}$ according to stations (spatial) at each month (temporal) in Tiworo Strait waters of Southeast Sulawesi, Indonesia.

Table 3. Sex ratio (males : females) of $\mathrm{BSC}$ of $>9.0 \mathrm{CW}$ according to months (temporal) at each station (spatial) of Tiworo Strait of Southeast Sulawesi, Indonesia.

\begin{tabular}{ccccccccc}
\hline Station & Jun & Jul & Aug & Sept & Oct & Nov & Dec & $\begin{array}{c}\text { Overall } \\
\text { sex ratio }\end{array}$ \\
\hline Sta $-\mathbf{A}$ & $1.09: 1.00$ & $1.00: 13.00$ & $1.00: 2.86$ & $1.00: 3.00$ & $1.00: 7.40$ & $1.00: 3.00$ & $7.00: 1.00$ & $1: 1.58$ \\
Sta $-\mathbf{B}$ & $11.00: 1.00$ & $1.00: 3.00$ & - & - & $8.00: 1.00$ & $3.50: 1.00$ & $1.00: 1,38$ & $1: 1.26$ \\
$\mathbf{S t a}-\mathbf{C}$ & $1.00: 2.00$ & $1.00: 0$ & $1.25: 1.00$ & - & $1.00: 2.00$ & $2.00: 0$ & - & $1: 1.16$ \\
$\mathbf{S t a}-\mathbf{D}$ & $1.00: 1.60$ & $1.00: 1.00$ & $1.00: 1.75$ & $1.00: 3.67$ & $1.00: 1.58$ & $1.00: 7.00$ & $1.43: 1.00$ & $1: 1.03$ \\
$\mathbf{S t a}-\mathbf{E}$ & $1.00: 6.00$ & $1.00: 1.00$ & $2.33: 1.00$ & $1.00: 1.05$ & $1.83: 1.00$ & $1.85: 1.00$ & $2.00: 0$ & $2.17: 1$ \\
$\begin{array}{c}\text { Overall } \\
\text { sex ratio }\end{array}$ & $1: 1$ & $1: 3.60$ & $1: 1.31$ & $1: 1.63$ & $1: 1.48$ & $1: 1.11$ & $1.42: 1$ & $1: 1.28$ \\
\hline
\end{tabular}




\section{Frequency (ind)}

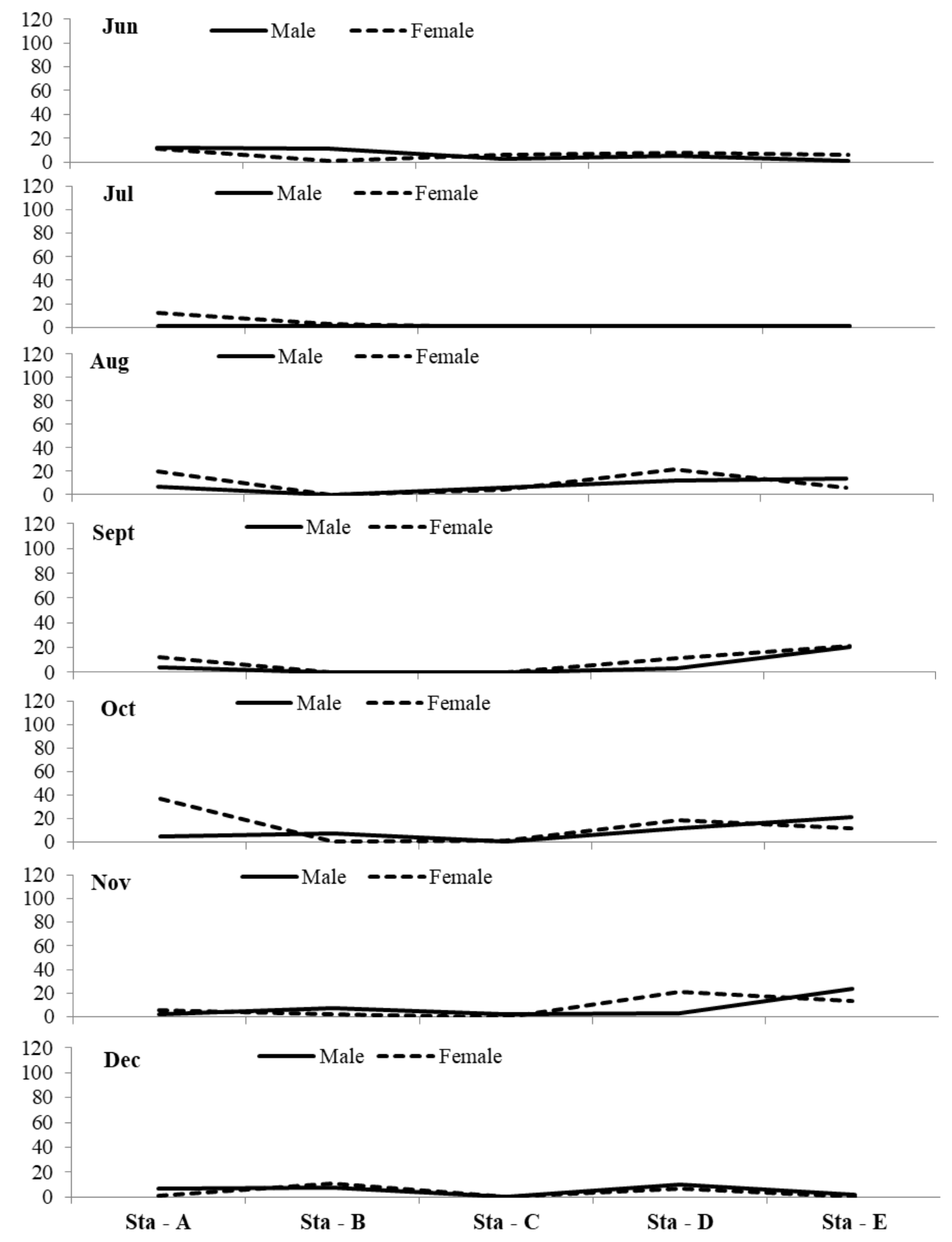

Fig. 9. Abundance of male and female BSCs of $>9.0 \mathrm{~cm} \mathrm{CW}$ according to months (temporal) at each station (spatial) in Tiworo Strait waters of Southeast Sulawesi, Indonesia. 


\section{DISCUSSION}

\section{Spatial and Temporal Abundance of CW Size Structure}

The species of BSC ( $P$. pelagicus) lives in a wide range of nearshore marine and estuarine waters throughout the Indo-West Pacific (Stephenson, 1962, Kailola et al., 1993), Red Sea, Suez Canal and the Middle-Eastern coast of the Mediterranean Sea (Mehanna and Haggag, 2007, Mehanna and El-Aiatt, 2011). In Tiworo strait this species was found all year rounds at different habitat characteristics (La Sara et al., 2016a), such as at intertidal zone (station A), river mouth (station B), seagrass with fine and coarse sandy substrate (stations $\mathrm{C}$ and $\mathrm{D}$ ), and deep-sea water of $>30 \mathrm{~m}$ (station E). Its abundance in those habitats is different depending on each habitat characteristics (spatial) and season of each month (temporal). Abundance of juvenile BSCs according to station characteristics (spatial) and month (temporal) (Figs. 4 and 5) and mature BSCs (Figs. 6 and 7) showed that both those sizes were dominant found at intertidal zone, closed to mangrove area and sandy substrate (station A). There were studies showed that this species lives in inshore and continental shelf areas, including sandy, muddy or algal and seagrass habitats, from the intertidal zone to at least $50 \mathrm{~m}$ depth (Williams, 1982, Edgar, 1990, Kailola et al., 1993). They are also usually found in large numbers in shallow bays with sandy bottom (William, 1974, Batoy et al., 1987) and are important commercial species in Tiworo strait and many other coastal waters in Indonesia, Southeast Asia countries, and Persian Gulf countries (Willams, 1974, Batoy et al.. 1987, Hosseini et al., 2014). However, La Sara et al. (2016a) found that juvenile BSCs are generally found at intertidal zone closed to mangrove forests with sandy mixed muddy substrates. Moreover, La Sara et al. (2019) suggested that such habitat characteristics (station A) are recommended to be a BSC nursery ground.

The BSC abundance found at river mouth (station B) was very few. The salinity at this station was low $(12-18 \mathrm{ppt})$, high current water and substrate dominated by mud. The relatively similar abundance was found at habitats dominated by seagrass and coarse sandy substrates (station $\mathrm{C}$ and $\mathrm{D}$ ). This data implies that such habitat characteristics are not preferred by BSC of all sizes. The juvenile BSCs which grow to be the mature BSC will occupy several habitat types and its abundance pattern is no regular pattern (Figs. 6 and 7). However, the mature BSC is still more abundant found at station A compared to other stations B, C, D and E. Generally, the mature BSCs and adults will move forward to deep sea water. BSCs move to deeper water as they mature and in response to water temperature and salinity (Kailola et al., 1993, de Lestang et al., 2010, Johnston et al., 2011). Those two water parameters can also affect size at sexual maturity in crabs (Rasheed and Mustaquim, 2010). Fisher (1999) who investigated effect of temperature and salinity on size at sexual maturity of female blue crab Callinectes sapidus from nine Texas bay systems stated that size at maturity can vary along the Texas coast, as temperature and salinity vary from bay to bay. He also mentioned that seasonal and annual variations in temperature and salinity in the bay could also affect size at onset of maturity. When the female BSCs reach maturity, they immediately move to deep water. This condition happens all most in all portunid mature particularly female is more abundant in deep water, while juveniles are always very few.

Similar data is shown by La Sara et al. (2016a). Data in Figs. 8 and 9 shows that the adult BSCs are few at stations A, as well as at stations B, C, and D, while at station E 
they show increasing in number. Those data show different habitats of BSC following its life stage namely juveniles occupy shallow water at intertidal zone closed to mangrove forests with sandy substrate (station A), while the mature BSCs occupy variable habitats (all stations) without regular pattern. It is clearly that adult BSCs occupy deep water (station E) which probably they maintain their eggs development for females (ovigerous females) up to spawning occurs (de Lestang et al., 2003). In the previous study in western Australia waters had been shown its historically large fluctuations in commercial BSC catches in Cockburn Sound (Johnston et al., 2011) which have previously been attributed to changes in commercial fishing practices, normal variations in recruitment and natural mortality (Bellchambers et al., 2006). The resultant collapse of the BSC fishery in Cockburn Sound can be attributed to a combination of factors related to the biology and distribution of this species, fishery dependent influences and environmental conditions (Johnston et al., 2011).

\section{Spatial and Temporal Sex Ratio}

Difference in sex abundance according to life stages of portunid and other crustaceans causes difference in sex ratio (biased sex ratio). Sex ratio of male juvenile BSCs is always preponderated over females at station A (overall sex ratio of $\mathrm{M}: \mathrm{F}=1.25$ : 1) and part of station $\mathrm{D}$ (overall sex ratio of $\mathrm{M}: \mathrm{F}=1.49: 1$ ), while at the other stations show no regular pattern (Table 1). It also happens in the mature BSC sex ratio (Table 2) and adult (Table 3). There are many factors cause variations (biased) sex ratio in portunid. Johnston et al. (2011) elaborate pattern of variation in sex ratio of the commercial catch was consistent between years in Western Australia. The authors stated further that during the closure period of the fishery since December 2006, the ratio of male and female crabs caught in traps at different times of the year has changed. For example, catches during the summer months are still dominated by male crabs, with $69-$ $81 \%$ of the catch being male between January and March, while female crabs enter traps in March/April, males continue to make up the majority of the catch until June and are caught in significant quantities through to December when they become dominant in catches again.

La Sara et al. (2016a) explained that sex ratio differences may be affected by seasons change, habitat characteristics differences (spatial differences), differential life span, migration pattern, food availability, changes in feeding behavior of female BSCs during spawning seasons (Potter and de Lestang, 2000, de Lestang et al., 2003), methods of capture and fishing gears used (Xiao and Kumar, 2004, La Sara et al., 2016c), gillnet catchability between sexes (Ingles, 1996), sampling frequency, growth and mortality rates, geographical position (tropical and subtropical regions) (Kumar et al., 2000, La Sara, 2001a), and differences in fishing skills and modes of operation of individual fishers (Xiao and Kumar, 2004). According to Archambault et al. (1990) and Ault et al. (1995), water salinity fluctuation affected size distribution on American blue crab C. sapidus, while La Sara et al. (2016a) stated that water temperature may also affect feeding behavior and activities searching for food leading to the fishing gears rely on bait (such as traps) or migration of BSCs (such as gillnets).

Previous study explained that changes in feeding behavior can also reduce the attractiveness of commercial pots to female crabs during the spawning period (Xiao and Kumar, 2004). They also demonstrated that sex ratio of BSC in commercial catches varied strongly with season in Australia, possibly because male and female crabs seem to 
prefer different habitats (characteristic of salinity and temperature differential distributions) at different times of the year (Meagher, 1971). Those water parameters also affect strongly the reproductive cycle of BSCs as shown in Cockburn Sound (de Lestang et al., 2010) which in turn will affect distribution pattern of each phase of larvae, juveniles, matures, and adults in its life cycle. Kumar et al. (2000) stated that growth and reproduction activities may affect sex ratio. Monthly sampling frequency of BSCs in off southern Australia waters was found males juvenile were outnumbered females namely male-to-female ratio 1: 0.71 (Xiao and Kumar, 2004). Similar studies in Karnataka, southern India showed $51 \%$ males and $49 \%$ females (Dineshbabu et al., 2008) and in Trang, Thailand showed males outnumbered females of $1.17: 1$ (Nitiratsuwan et al., 2013). According to Sumpton et al. (1994) that a low percentage of female crabs in commercial catches in Moreton Bay during the spawning period has been attributed to the migration of mature females onto sand banks for extrusion of eggs.

It has been reported that a sandy substrate is required for successfully extruding their eggs from its pleopods to be released to sea water. Those studies are different with the previous study on BSC taken from Tiworo Strait using rectangular collapsible traps and bottom gillnets which showed generally sex ratio of females preponderated over males (male: female $=1:$ 1.032) (La Sara et al., 2016a). Similar results were showed a study on BSC taken in ecosystems of mangroves, seagrass, and coral reefs in Salemo Island, South Sulawesi which males preponderated over females namely in the respective 1.1 : 1, $1.7: 1$, and $1.01: 1$ (Nurdin et al., 2016). Other studies on Portunid in different regions also may show differences or biased sex ratio due to species differences, sampling frequency, locations, and fishing gears used (Table 4). The present study gives wide variation of sex ratio due to different sampling stations (spatial) and variation of monthly sampling (temporal). Archambault et al. (1990) explained that spatial separation of both sexes can explain part of the differences, as shown in $C$. sapidus at Charleston Harbor. The present study showed fluctuation of sex ratio according to growth phase of BSC in Tiworo Strait, Southeast Sulawesi. The data of sex ratio (Table 4) are very important to be used as an indicator to assess the ability of the blue swimming crab maintains the running recruitment (Ault et al., 1995).

Table 4. Sex ratio of Portunids from different regions.

\begin{tabular}{cllcl}
\hline No. & Locations & Species & Sex ratios & References \\
\hline 1. & Lawele Bay, Indonesia & Scylla serrata & $7.25: 1$ & La Sara (2001b) \\
& & S. tranquebarica & $1.14: 1$ & \\
2. & Ragay Gulf, Philippines & P. pelagicus & $23: 1$ & Ingles and Braum (1989) \\
3. & Bantayan waters, Philippines & P. pelagicus & $1: 1.63$ & Ingles (1996) \\
4. & Bandar Abbas, Persian Gulf & P. pelagicus & $1: 1.2$ & Kamrani et al (2010) \\
5. & Karnataka waters, India & P. sanguinolentus & $1.13: 1$ & Dineshbabu et al (2007) \\
6. & Leschenaukt Estuary, Australia & P. pelagicus & $1: 1.8$ & Potter and de Lestang \\
& & & $1: 1.032$ & La Sara et al (2016a) \\
7. & Tiworo Strait, Indonesia & P. pelagicus & $1:>1$ & Astuti et al (2019) \\
8. & Tiworo Strait, Indonesia & P. pelagicus & Tables 1, 2, & Present study \\
9. & Tiworo Strait, Indonesia & P. pelagicus & and 3 & \\
& & & & \\
\hline
\end{tabular}




\section{CONCLUSION}

It is apparent that abundance of juvenile BSCs found in entire habitats of Tiworo Strait from intertidal zone up to deep water of $>30 \mathrm{~m}$ is higher in intertidal zone in all year around which they prefer to habitat closed to mangrove forests with sandy substrate. Such habitat characteristics are suggested to be protected as nursery ground. The abundance of mature BSCs in this waters does not performance regular pattern, while adult BSCs tends to increase in deep water in all year rounds which mainly relates to female BSCs psychological extrude their eggs. Those abundance patterns affect BSC sex ratio distribution. It is found that male juvenile BSCs preponderated over females in all stations and all year rounds. In contrary, sex ratio of female mature BSCs preponderated over males in all stations except in station E, while sex ratio of adult BSCs varied at each station but the overall sex ratio of females preponderated over males as well as mature BSCs. This is a fact that female adult BSCs prefer saline water to extrude their eggs.

\section{ACKNOWLEDGEMENT}

This manuscript is a part of a research funded by "Badan Layanan Umum" of Halu Oleo University 2019 , which is gratefully acknowledged. The authors would like to thank to Head of Research and Services Institution of Halu Oleo University Who provided grant for this research through Intern Basic Research of Halu Oleo University. They also thanked to our students who involved during monthly data collection in Tiworo Strait.

\section{REFERENCES}

Apel, M. and Spiridonov, V. A. (1998). Taxonomy and zoogeography of the Portunid crabs (Crustacea: Decapoda: Brachyura: Portunidae) of the Arabian Gulf and Adjacent Waters. Fauna of Arabia, 17: 159-331.

Archambault, J. A.; Wenner, E. L. and Whitaker, J. D. (1990). Life history and abundance of blue crab, Callinectes sapidus Rathbun, at Charleston Harbor, South Carolina. Bulletin of Marine Science, 46(1): 145-158.

Astuti, O.; Alimina, N.; Emiyarti; Nurgayah, W.; Rahmadani; Ira, SKel. and La Sara. (2019). Length- weight relationship, growth pattern and relative condition factor of blue swimming crab (Portunus pelagicus) in Tiworo Strait waters, Southeast Sulawesi. In La Sara, Indrayani and Wa Iba (Eds.). Proceeding of the $3^{\text {rd }}$ National Seminar on Sustainability Fisheries and Marine Resources- "Innovation Implementation of Science and Technology of Marine and Fisheries in Achieving SDGs-14" (pp. 97-112). Kendari, Indonesia. FPIK Press. 287 pp (In Indonesian).

Ault, J. S.; Patrick, E. V. and Rothschild, B. J. (1995). Physical factors affecting recruitment and abundance of the Chesapeake Bay blue crab stock. Bulletin of Marine Science, 57(3): 917.

Basri, M. I.; La Sara. and Yusnaini. (2017). Aspects of reproductive biology as a basic of management of blue swimming crab (Portunus pelagicus, Linn 1758) in Toronipa waters of Konawe). Journal of Fishery Science and Innovation, 1(2): 1625 (in Indonesia).

Batoy, C. B.; Sarmago, J. F. and Pilapil, B. C. (1987). Breeding season, sexual maturity and fecundity of the blue crab, Portunus pelagicus (L.) in selected coastal 
waters in Leyte and vicinity, Philippines. Annals of Tropical Research, 9: 157-177. DOI: 10.32945/atr

Bellchambers, L.; de Lestang, S.; Smith, K. D.; Thomson, A. W. (2006). Catch prediction for the blue swimmer crab (Portunus pelagicus) in Cockburn Sound Western Australia. Bulletin of Marine Science, 79: 329-339.

Carpenter, K. E.; Krupp, F.; Jones, D. A. and Zajonz, U. (1997). FAO species identification field guide for fishery purpose. The Living Marine Resources of Kuwait, Eastern Saudi Arabia, Bahrain, Qatar, and the United Arab Emirates FAO Report, VII, 1-293.

de Lestang, S.; Hall, N. G. and Potter, I. C. (2003). Do the age compositions and growth of the crab Portunus pelagicus in marine embayments and estuaries differ? Journal of Marine Biology Association U.K, 83, 1-8. DOI: https://doi.org/10.1017/ S0025315403008166h.

de Lestang, S.; Bellchambers, L. M.; Caputi, N.; Thomson, A. W.; Pember, M. B.; Johnston, D. J. and Harris, D. C. (2010). Stock-recruitment-environment relationship for a Portunus pelagicus fishery in Western Australia. In: Kruse, G. H.; Eckert, G. L.; Foy, R. J.; Lipcius, R. N.; Sainte-Marie, B.; Stram, D. L. and Woodby, D. (eds.). Biology and management of exploited crab populations under climate change. Alaska Sea Grant, University of Alaska Fairbanks. doi:10.4027/bmecpcc.2010.06.

Dineshbabu, A. P.; Shridhara, B. and Muniyappa, Y. (2008). Biology and exploitation of the blue swimmer crab, Portunus pelagicus (Linnaeus, 1758), from South Karnataka Coast, India. Indian Journal of Fisheries, 55(3): 215-220. http://eprints.cmfri.org.in/id/eprint/106.

Edgar, G. J. (1990). Predator-prey interaction in seagrass beds. II. Distribution and diet of the blue manna crab Portunus pelagicus Linnaeus at Cliff Head, Western Australia. Journal of Experimental Marine Biology and Ecology, 139: 23-32. https://doi.org/10.1016/0022-0981(90)90035-B.

Fisher, M. R. (1999). Effect of temperature and salinity on size at maturity of female blue crabs. Transactions of the American Fisheries Society, 128(3): 499-506. https://doi.org/10.1577/1548-8659(1999)128<0499:EOTASO>2.0.CO;2.

Hisam, F.; Hajisamae, S.; Ikhwanuddin, M.; Aziz, N. A. N.; Naimullah, M. and Hassan, M. (2018). Study on the reproductive biology of the blue swimming crab, Portunus pelagicus females from Pattani Coastal Waters, Thailand. AACL Bioflux, 11(6): 1776-1791.

Hosseini, M.; Pazooki, J. and Safaei, M. (2014). Size at maturity, sex ratio and variant morphometrics of blue swimming crab Portunus segnis (Forskal, 1775) from Boushehr Coast (Persian Gulf). Journal of Marine Science: Research \& Development, 4(2): 149. doi:10.4172/2155-9910.1000149.

Ingles, J. A. (1996). The crab fisheries off Bantayan, Cebu, Philippines. IMFO-CF, University of the Philippines - PCMARD, Philippines, $88 \mathrm{pp}$.

Ingles, J. A. and Braum, E. (1989). Reproduction and larval ecology of the blue swimming crab, Portunus pelagicus, in Ragay Gulf, Philippines. Internationale Revue der gesamten Hydrobiologie und Hydrographie, 74(5): 471-490. https://doi.org/10.1002/iroh.19890740503. 
Johnston, D.; Harris, D.; Caputi, N. and Thomson, A. (2011). Decline of a blue swimmer crab (Portunus pelagicus) fishery in Western Australia - History, contributing factors and future management strategy. Fisheries Research, 109: 119130. https://doi.org/10.1016/j.fishres.2011.01.027.

Kailola, P. J.; Williams, M. J.; Stewart, P. C.; Reichelt, R. E.; McNee, A. and Grieve, C. (1993). Australian fisheries resources. Bureau of Resource Sciences, Department of Primary Industries and Energy, Canberra, Australia, 422 pp.

Kamrani, E.; Sabili, A. N. and Yahyavi, M. (2010). Stock assessment and reproductive biology of the blue swimming crab, Portunus pelagicus in Bandar Abbas Coastal Waters, Northern Persian Gulf. Journal of the Persian Gulf (Marine Science), 1(2): 11-22.

Kumar, M.; Ferguson, G.; Xiao, Y.; Hooper, G. and Venema S. (2000). Studies on reproductive biology and distribution of the blue swimmer crab (Portunus pelagicus) in South Australian waters. South Australian Research and Development Institution (SARDI), Australia, $35 \mathrm{pp}$.

La Sara (2001a). Ecology and fisheries of mud crab Scylla serrata in Lawele Bay, Southeast Sulawesi, Indonesia (PhD Dissertation). University of the Philippines in the Visayas. Miagao, Iloilo, Philippines.

La Sara (2001b). Habitat and some biological parameters of two species of mud crab Scylla in Southeast Sulawesi, Indonesia. In Carman O.; Sulistiono; Purbayanto, A.; Suzuki, T.; Watanabe, S. and Arimoto, T. (Eds). Proceeding of the JSPS-DGHE International Symposium on Fisheries Science in Tropical Area (pp. 341-346). TUF International JSPS Project Vol. 10, Konan Minato-ku, Tokyo, Japan.

La Sara; Muskita, W. H.; Astuti, O. and Safilu. (2016a). The Reproductive biology of blue swimming crab Portunus pelagicus in Southeast Sulawesi waters, Indonesia. AACL Bioflux, 9(5): 1101-1112.

La Sara; Muskita, W. H.; Astuti, O. and Safilu. (2016b). Effort in harvest control for blue swimming crab (Portunus pelagicus) in Southeast Sulawesi, Indonesia. Paper presented in the Crustacean Society Mid-Year Meeting 2016, National University of Singapore, Singapore, 11-13 July 2016.

La Sara; Halili; Mustafa, A. and Bahtiar. (2016c). Appropriate escape vent sizes on collapsible crab pot for blue swimming crab (Portunus pelagicus) fishery in Southeast Sulawesi waters, Indonesia. Journal of Fisheries and Aquatic Science, 11: 402-410. DOI: $10.3923 /$ jfas.2016.402.410.

La Sara; Muskita, W. H.; Astuti, O. and Safilu. (2017). Some population parameters of blue swimming crab (Portunus pelagicus) in Southeast Sulawesi waters, Indonesia. AACL Bioflux, 10(3): 587-601.

La Sara; Astuti, O.; Muzuni, and Safilu. (2019). Status of blue swimming crab (Portunus pelagicus) population in Southeast Sulawesi waters, Indonesia. AACL Bioflux, 12(5): 1909-1917.

Meagher, T. D. (1971). Ecology of the crab Portunus pelagicus in South Western Australia (PhD Thesis. University of Western Australia, Australia.

Mehanna, S. F. and El-Aiatt, A. (2011). Fisheries characteristics and population dynamics of the blue swimmer crab Portunus pelagicus (Linnaeus, 1766) from Bardawil lagoon. Egyptian Journal of Aquatic Biology and Fisheries, 15(3): 393406. 
Mehanna, S. F. and Haggag, H. M. (2007). Fisheries management of the blue swimmer crab Portunus pelagicus (Linnaeus, 1766) from Port Said at the Mediterranean coast of Egypt. In Proceeding of International Arab African Fish Resources Conference on Sustainable Use and Management of Aquatic Resources, 28-30 June 2007, Cairo, Egypt.

Muchtar, A. S.; La Sara, and Asriyana. (2017). Size structure and population parameters of blue swimming crab (Portunus pelagicus, Linnaeus 1758) in Toronipa waters, Southeast Sulawesi, Indonesia). Journal of Fishery Science and Innovation, 1(1): 1-8. (In Indonesian).

Nitiratsuwan, T.; Suwat, T. and Kansinee, P. (2013). Distribution of berried female blue swimmer crabs (Portunus pelagicus Linneaus, 1758) in the Coastal waters of Trang Province, Southern Thailand. Maejo International Journal of Science and Technology, 7: 52-59.

Nurdin, M. S.; Ali, S. A. and Satari, D. Y. (2016). Sex ratio and size at first maturity of blue swimming crab (Portunus pelagicus) at Salemo Island, South Sulawesi. Journal of Marine Science (Ilmu Kelautan), 21(1): 17-22.

Potter, I. C. and de Lestang, S. (2000). Biology of the blue swimmer crab Portunus pelagicus in Leschenault estuary and Koombana bay, South-western Australia. Journal of the Royal Society of Western Australia, 83: 443-458. http://www.rswa.org.au/.

Rasheed, S. and Mustaquim, J. (2010). Size at sexual maturity, breeding season and fecundity of three-spot swimming crab Portunus sanguinolentus (Herbst, 1783) (Decapoda, Brachyura, Portunidae) occurring in the coastal waters of Karachi, Pakistan. Fisheries Research, 103(1): 56-62. DOI: 10.1016/j.fishres.2010.02.002.

Stephenson, W. (1962). The evolution and ecology of Portunid Crabs with, special reference to Australian species. In Leeper, G. W. (Ed.). The evolution of living organisms (pp.311-327). Melbourne, Australia. Melbourne University Press.

Sumpton, W. D.; Potter, M. S. and Smith, G. S. (1994). Reproduction and growth of the commercial sand crab, Portunus pelagicus (L.) in Moreton bay, Queensland. Asian Fisheries Science, 7: 103-113.

Sudjana. (1989). Statistics method. Bandung, Indonesia, Tarsito Press., 508 pp. (in Indonesian).

Williams, A. B. (1974). The swimming crabs of the genus Callinectes (Decapoda: Portunidae). United States Fishery Bulletin, 72(3): 685-692.

Williams M. J. (1982). Natural food and feeding in the commercial sand crab Portunus pelagicus Linnaeus, 1766 (Crustacea: Decapoda: Portunidae) in Moreton bay, Queensland. Journal of Experimental Marine Biology and Ecology, 59(2 \& 3): 165 176. https://doi.org/10.1016/0022-0981(82)90113-7.

Xiao, Y. and Kumar, M. (2004). Sex ratio and probability of sexual maturity of females at size of the blue swimmer crab, Portunus pelagicus Linneaus, off Southern Australia. Fisheries Research, 68(1 \& 3): 271-282. https://doi.org/10.1016/ j.fishres.2003.11.012.

Zairion; Wardiatno, Y.; Boer, M. and Fahrudin, A. (2015). Reproductive biology of the blue swimming crab Portunus pelagicus (Brachyura: Portunidae) in East Lampung waters, Indonesia: Fecundity and reproductive potential. Tropical Life Sciences Research, 26(1): 67-85. 